\title{
PERAN GURU DALAM MENGOPTIMALKAN TUGAS-TUGAS PERKEMBANGAN PADA ANAK USIA DINI
}

\author{
Aghnaita $^{1}$, Irmawati $^{2}$, Maimun Paus ${ }^{3}$ \\ ${ }^{1}$ PIAUD, Fakultas Tarbiyah dan Ilmu Keguruan, IAIN Palangkaraya, \\ ${ }^{2}$ PIAUD, Fakultas Tarbiyah dan Ilmu Keguruan, IAIN Palu \\ ${ }^{3}$ PIAUD, Fakultas Ilmu Tarbiyah dan Ilmu Keguruan, UIN Sunan Kalijaga Yogyakarta \\ Email: Aghnaita94@gmail.com
}

\begin{abstract}
ABSTRAK
Penelitian ini bertolak dari konsep tentang usia kelahiran hingga memasuki pendidikan dasar sebagai masa keemasan, sekaligus masa kritis dalam tahapan kehidupan yang akan menentukan perkembangan selanjutnya. Oleh sebab itu, sangatlah penting adanya upaya untuk mengembangkan seluruh potensi anak yang harus dimulai sejak dini secara optimal. Selain itu, perkembangan anak yang akan berhadapan dengan fenomena budaya yang berbeda-beda, akan memunculkan sejumlah tugas perkembangan yang harus diselesaikan sesuai dengan periode usianya masing-masing. Sejalan dengan hal ini maka diperlukan adanya bantuan dari lingkungan sekitar, salah satunya yakni peran guru di sekolah. Berdasarkan hasil penelitian, maka dapat diperoleh bahwa tugas perkembangan merupakan tugas yang muncul pada periode tertentu dalam rentang kehidupan individu. Guru sebagai bagian dari sekolah yang merupakan lembaga pendidikan formal dimana secara sistematik dalam melaksanakan program, turut berperan dalam mengembangkan tugas perkembangan anak. Di antaranya melalui kelompok teman sebaya, perkembangan kemandirian pribadi, keimanan dan ketakwaan kepada Tuhan Yang Maha Esa, serta melaksanakan pembelajaran berbasis perkembangan.
\end{abstract}

Kata Kunci: peran, guru, tugas perkembangan, anak usia dini

\begin{abstract}
ABSTRACK
This research departs from the concept of age of birth to enter primary education as a golden period, as well as a critical period in the stages of life that will determine further development. Therefore, it is very important that there are efforts to develop the full potential of children which must be started early in an optimal manner. In addition, the development of children who will be dealing with different cultural phenomena, will bring up a number of developmental tasks that must be completed in accordance with their respective age periods. In line with this, assistance from the surrounding environment is needed, one of which is the role of teachers in schools. Based on the results of the study, it can be obtained that the task of development is a task that appears at a certain period in the life span of an individual. The teacher as part of the school which is a formal educational institution where systematically in implementing the program, also plays a role in developing children's development tasks. Among them through peer groups, the development of personal independence, faith and piety to God Almighty, as well as carrying out development-based learning.
\end{abstract}

Keywords: role, teacher, development task, early childhood 


\section{PENDAHULUAN}

Anak usia dini dalam rentang antara pasca kelahiran hingga memasuki usia pendidikan dasar sering disebut sebagai masa keemasan sekaligus masa kritis dalam proses kehidupan. Di sisi lain, masa ini menjadi suatu keadaan yang krusial dan penting dalam penanaman pondasi bagi anak yang akan berpengaruh bagi perkembangan selanjutnya. Oleh sebab itu, pentingnya suatu upaya untuk mengoptimalkan berbagai potensi yang harus dimulai sejak dini agar dapat tercapai dengan baik (Mansur, 2014).

Pada dasarnya, perkembangan dapat dimaknai sebagai proses perubahan yang signifikan dan kontinu. Perubahan yang dimaksud merupakan perubahan psikofisik sebagai hasil dari adanya proses pematangan fungsifungsi psikis dan fisik yang mendapat dukungan dari lingkungan serta adanya kesempatan belajar. Perkembangan fisik berkaitan dengan perubahan fisik, sedangkan perkembangan psikis berkaitan dengan perkembangan sosial, emosional, intelektual, dan spiritual (Thalib, 2010).

Perkembangan mencakup seluruh aspek kepribadian di mana antara satu aspek dan aspek lainnya saling berkaitan. Sebagian besar dari perkembangan aspek-aspek kepribadian terjadi melalui proses belajar mulai dari hal yang sederhana hingga kompleks (Rochmah, 2005). Pada dasarnya setiap tahapan perkembangan seorang anak terjadi sejalan dengan adanya peluang belajar yang diberikan. Proses belajar yang dimaksud lebih bermakna kepada capaian-capaian yang harus dituntaskan anak di setiap fase perkembangan sebelum menuju pada fase selanjutnya yang lebih kompleks. Hal ini bersifat normal di mana setiap anak akan melalui setiap tugas perkembangan tersebut berdasarkan kemampuan yang dimilikinya (Syah, 2013).

Adapun dari sisi budaya, individu harus menyelesaikan tugas perkembangan sesuai dengan periode umurnya (Sumanto, 2014). Tugas perkembangan ini sangatlah berperan dalam aspek perkembangan anak. Sehingga dapat dilihat perkembangan anak yang terjadi telah sesuai dengan tugas-tugas perkembangan pada fasefasenya atau sebaliknya.

Dewasa ini, proses pembelajaran bagi anak usia dini mendapatkan suatu perhatian yang khususm tidak terkecuali di Indonesia. Hal ini dikarenakan pembelajaran yang dilakukan cenderung berorientasi akademik serta hanya berfokus pada pencapaian anak dalam kegiatan membaca, menulis, dan menghitung. Sudah semestinya pembelajaran bagi anak usia dini lebih diarahkan untuk mengoptimalkan berbagai potensi secara menyeluruh (Ismail, 2009).

Di sisi lain, tingkat pencapaian anak dalam perkembangannya tidak terlepas dari adanya peran tripusat pendidikan. Di antaranya adalah pihak sekolah, seperti kepala sekolah dan guru. Bagi pendidikan anak usia dini, guru adalah kunci keberhasilan anak dan sebagai pengganti orang tua di rumah. Sesuai tahap perkembangannya, segala tampilan guru akan dipersepsi dan dinilai oleh anak. Kepribadian seorang guru akan menjadi bagian dari 
Aghnaita, Irmawati, Maimun Paus. PERAN GURU DALAM MENgOPTIMALKAN TUGASTUGAS PERKEMBANGAN PADA ANAK USIA DINI. Early Childhood : Jurnal Pendidikan. Vol. 4 No. 1, Mei 2020

figur teladan bagi anak (Ismail, 2009). Berangkat dari hal tersebut maka guru memilliki peran yang sangat krusial dalam rangka mengoptimalkan tugastugas perkembangan pada anak usia dini.

Pianta mengungkapkan, pada periode ini guru menjadi faktor kedua setelah orang tua yang paling berpengaruh dalam perkembangan anak. Guru juga memiliki peranan penting dalam menentukan kondisi anak saat di sekolah serta mengenalkan berbagai keterampilan dasar bagi anak (Yoleri, 2016). Selanjutnya, penelitian lain yang dilakukan oleh Baker, dkk telah menunjukkan bahwa kualitas hubungan antara guru dan anak tidak hanya memengaruhi perkembangan sosial dan emosionalnya saja, akan tetapi juga hubungan anak dengan teman sebaya, keberhasilan akademis, dan status anak di sekolah (Yoleri, 2016).

Beberapa penelitian menunjukkan jika kualitas hubungan antara guru dan anak sangat penting dan turut menentukan terhadap hasil belajar anak sepanjang masa kanak-kanaknya. Oleh sebab itu, hubungan guru dan anak yang positif akan berperan dalam mendukung keberhasilan anak itu sendiri. Adapun hubungan guru dan anak yang negatif akan dapat menghambat prestasi dan perkembangan anak sehingga dapat menyebabkan masalah pribadi (Yoleri, 2016).

Hal tersebut juga sejalan dengan yang telah diungkapkan oleh Kontos \& Wilcox-Herzog, bahwa adanya konsensus umum terhadap suatu fakta bahwa kualitas pendidikan prasekolah tergantung pada kualitas hubungan guru dan anak. Hubungan yang dimaksud adalah tidak hanya menandakan hanya pada kontribusi positif terhadap perkembangan anak saja, namun juga berdampak pada pengembangan keterampilan sosial dan akademik anak (Yoleri, 2016).

Berdasarkan pemaparan yang ada, maka tujuan dari penelitian ini yaitu untuk mengetahui berbagai tugas perkembangan anak usia dini dan peran guru dalam mengoptimalkannya. Selain itu, anak dapat mencapai setiap tahapan perkembangan dengan baik serta menjadi bagian dari langkah preventif yang dapat diambil guna meminimalisir kegagalan perkembangan yang dapat terjadi.

\section{PEMBAHASAN}

\section{Pengertian dan Sumber Tugas-tugas Perkembangan}

Menurut Robert Havighurst yang dikutip oleh Syamsu Yusuf melalui perspektif psikososial, berpendapat bahwa adanya periode yang beragam dalam kehidupan seseorang membawa kepada berbagai tugas perkembangan yang harus dilalui dengan baik. Selanjutnya, tugas-tugas ini nantinya secara tidak langsung akan berhubungan dengan berbagai permasalahan yang akan dihadapinya pada masa yang akan datang.

Menurut Havighurst yang dikutip oleh Syamsu Yusuf, mengungkapkan bahwa tugas-tugas perkembangan sebagai suatu tugas yang muncul pada periode dan rentang kehidupan individu tertentu (LN, 2014). Adapun Hurlock menyebut tugas-tugas perkembangan ini sebagai social expectations. Hal 
Aghnaita, Irmawati, Maimun Paus. PERAN GURU DALAM MENgOPTIMALKAN TUGASTUGAS PERKEMBANGAN PADA ANAK USIA DINI. Early Childhood : Jurnal Pendidikan. Vol. 4 No. 1, Mei 2020

tersebut mengisyaratkan bahwa setiap keberhasilan yang diperoleh individu dalam melewati setiap tugas perkembangan ini turut berdampak terhadap penyelesaian tugas-tugas berikutnya. Lebih jauh lagi, hal ini juga berpengaruh kepada penerimaan sosial budaya masyarakat setempat terhadap individu tersebut.

Oleh sebab itu, tugas-tugas perkembangan tersebut sepatutnya harus selalu dipertimbangkan secara teliti oleh orang tua maupun guru sebagai proses yang harus dilalui secara alami oleh anak. Perhatian lingkungan sekitar terutama orang tua dan guru merupakan hal yang urgen mengingat keberhasilan pelaksanaan tugas perkembangan pada masa krusial anak menentukan tingkat keberhasilan pada tugas perkembangan di fase berikutnya (Syah, 2013). Ada beberapa faktor yang mendasari tugas-tugas perkembangan bagi anak usia dini, yaitu:

1. Kematangan fisik tertentu.

2. Tuntutan masyarakat secara kultural.

3. Tuntutan yang berasal dari keinginan individu sendiri.

4. Tuntutan norma agama (LN, 2014).

Di sisi lain, dalam menjalankan tugas perkembangan ada beberapa faktor yang dapat menyebabkan anak gagal memenuhi tugas perkembangannya dengan baik, seperti:

1. Retardasi dalam perkembangan, disebabkan karena kondisi fisik dan keterbelakangan mental.

2. Kurangnya kesempatan dalam mempelajari tugas-tugas perkembangan.
3. Kurangnya motivasi bagi anak.

Pada masa inilah anak mengalami yang dinamakan critical age (masa kritis). Hal tersebut disebabkan karena masa ini menjadi tolak ukur dalam perkembangan anak dalam jangka panjang. Selain itu, adanya dukungan lingkungan turut menentukan keberhasilan anak dalam melalui tahapan penting tersebut. Jika gagal, maka perkembangan anak tidak akan dapat menuju pada pencapaian perkembangan yang ideal. Pada masa kritis ini, faktor kematangan juga menjadi landasan yang menentukan tingkat keberhasilan anak. Ada empat aspek yang saling berkaitan dan turut menentukan arah pencapaian dari tugas perkembangan, yaitu:

1. Adanya kemungkinan perilaku baru yang muncul atau perilaku orang lain yang lebih matang darinya.

2. Memahami konsep baru terhadap dirinya sendiri (identity formation).

3. Mampu menghadapi permasalahan yang ada secara efektif baik dikarenakan dorongan eksternal maupun internal.

4. Keinginan untuk mencapai langkah selanjutnya dalam perkembangan (motivasi) (Rochmah, 2005).

Berdasarkan hal ini, maka dapat diambil garis besarnya, bahwa dalam melakukan tugas perkembangan, sangat dipengaruhi oleh proses pengalaman dan belajar yang dialami anak. Selain itu, anak juga melalui proses asimilasi serta modifikasi terhadap apa yang telah diperolehnya serta proses adaptif akan lingkungannya. 
Aghnaita, Irmawati, Maimun Paus. PERAN GURU DALAM MENgOPTIMALKAN TUGASTUGAS PERKEMBANGAN PADA ANAK USIA DINI. Early Childhood : Jurnal Pendidikan. Vol. 4 No. 1, Mei 2020

\section{Tugas-tugas Perkembangan pada Fase Perkembangan Anak}

Menurut Syamsu Yusuf LN, tugas perkembangan pada fase anak usia dini secara umum dibagi menjadi 2 periode, yaitu: pada usia bayi dan kanak-kanak (0-6 tahun) dan usia sekolah (6-12 tahun). Secara rinci akan dijelaskan sebagai berikut.

1. Tugas-tugas Perkembangan pada Usia Bayi dan Kanak-kanak Awal (0-6 tahun)

Hurlock menyatakan bahwa adanya tugas perkembangan dimaksudkan sebagai acuan anak untuk memahami berbagai hal yang diharapkan serta berlaku secara sosial kemasyarakatan pada usia tertentu (Hidayati \& Purnami, 2008). Perkembangan biologis pada masa anak usia dini berkembang lebih cepat dibandingkan masa sesudahnya. Di sisi lain, anak sendiri belum memiliki kematangan yang menyeluruh sehingga sangat bergantung kepada lingkungan yang dapat mendukungnya secara optimal. Berdasarkan hal demikian, peran lingkungan pada masa ini sangat lah penting bagi anak guna mempersiapkannya dalam menghadapi lingkungan yang lebih luas (Syah, 2013).

\section{a. Belajar berjalan}

Perkembangan ini biasanya terjadi di usia 9-15 bulan. Tulang kaki, otot dan susunan syaraf anak mulai matang untuk dapat belajar berjalan. Beberapa kemampuan gerak penting yang telah dikuasai oleh anak sebelum belajar berdiri dan berjalan adalah merangkak dan duduk. Setelah anak dapat duduk dengan mantap, maka menyusul kemampuan-kemampuan gerak yang lain, seperti belajar berdiri yang awalnya melalui pertolongan, misalnya rambatan orang lain atau benda-benda tegak yang ada di sekitarnya.

Pada saat ini, anak-anak semakin senang karena lingkungan geraknya semakin luas. Hal ini memberi kesempatan anak untuk memperoleh dan melakukan permainan yang lebih banyak lagi. Gerak pindahnya tidak lagi bergantung pada orang dewasa, anak mempunyai kesempatan untuk melatih dirinya sendiri, misalnya bermain sendiri dengan teman-temannya. Kondisi ini berguna bagi anak dalam menstimulus kemandiriannya. Setelah anak dapat berjalan dengan stabil, maka mulailah ia belajar meloncat dan berlari (Fudyartanta, 2011).

b. Belajar makan makanan padat

Perkembangan ini berlangsung pada tahun kedua, dimana sejalan dengan kesiapan dari sistem pencernaan mulut yang telah matang. Tumbuhnya dentes decidui menyebabkan anak mampu mengunyah makanan-makanan yang padat. Air susu ibu sudah tidak cukup lagi untuk memenuhi pertumbuhan anak.

Anak-anak mulai tertarik untuk turut serta makan makanan padat bagi orang dewasa. Keinginan itu baik dinyatakan melalui bahasa atau reaksi lainnya, seperti rewel jika tidak diberi apa yang anak inginkan. Hal yang perlu mendapat perhatian ialah keteraturan dalam memberi makan pada anak baik pada waktu anak masih menyusu maupun masa-masa selanjutnya. Karena hal ini akan sangat memengaruhi 
Aghnaita, Irmawati, Maimun Paus. PERAN GURU DALAM MENgOPTIMALKAN TUGASTUGAS PERKEMBANGAN PADA ANAK USIA DINI. Early Childhood : Jurnal Pendidikan. Vol. 4 No. 1, Mei 2020

perkembangan kepribadian anak (Fudyartanta, 2011).

c. Belajar berbicara

Anak belajar berbicara berarti anak mengeluarkan suara yang memiliki makna serta dapat mengomunikasikannya kepada orang lain secara verbal. Oleh sebab itu, perlu adanya kematangan otot dan syaraf pada alat bicara. Ada dua pendapat mengenai awal anak dalam belajar berbicara, yaitu:

1) Pendapat pertama, bayi mulai belajar berbicara dengan cara meraban. Kemudian lingkungannya mengajarkan berbagai kosa kata serta menghubungkan suara tersebut dengan benda atau situasi tertentu.

2) Pendapat kedua, bayi mengeluarkan suara yang mengandung makna serta bagian dari ekspresi perasaan anak. Selanjutnya anak belajar bahasa melalui cara imitasi terhadap lingkungannya.

Pada waktu bayi dapat menggetarkan bibirnya dan menimbulkan suara (bunyi), bayi merasa senang. Selain itu, pada saat mendengarkan suara-suaranya sendiri dan orang lain, reaksi yang tampak ialah tersenyum, tertawa, dan mengulangi suara-suara yang dikeluarkannya. Unsur bahasa adalah salah satu aspek kebuadayaan manusia. Fungsi bahasa ialah untuk berkomunikasi di dalam masyarakat. Masyarakat yang maju, menghendaki supaya anak-anak sudah mampu mempergunakan bahasa. Hal ini sangat penting, terutama dalam proses hubungan sosial dan pendidikan. Sebaliknya ada suara-suara yang menyatakan sakit atau tidak senang, seperti menangis, dan berteriak. Hal ini timbul apabila si bayi menghadapi situasi yang tidak menyenangkan baginya (Fudyartanta, 2011).

d. Belajar buang air kecil besar.

Saraf-saraf urinasi mulai sempurna pada umur 2-4 tahun. Otototot dan rangka badan telah cukup kuat untuk beberapa kegiatan yang ringan. Selain itu anak juga belajar memelihara kebersihan tubuh dan pakaian serta kesehatannya (secara sederhana) (Fudyartanta, 2011).

e. Belajar mengenal perbedaan jenis kelamin.

Melalui observasi sederhana, anak dapat mengamati perbedaan tingkah laku, fisik maupun pakaian antara anak perempuan dengan anak laki-laki. Tugas perkembangan dalam hal ini bersifat sosiokultural. Karena mulai dari awal anak harus mengenal jenis kelamin dengan baik, dan orang dewasa berperan untuk mengajari bagaimana cara bertingkah laku yang sopan.

f. Mencapai kestabilan jasmaniah fisiologis.

Keadaan jasmani anak sangatlah rentan jika dibandingkan dengan orang dewasa. Perubahan suhu pada anak disebabkan temperature badannya yang cepat berubah-ubah. Di sisi lain, variasi makanan maupun nutrisi yang diberikan juga dapat mempengaruhi kadar garam dan gula dalam darah serta air di dalam tubuh. Hal ini berlangsung sampai anak memasuki usia 5 tahun. Pada fase ini, orang tua perlu memberikan perhatian yang intensif bagi anak.

g. Membentuk konsep (pengertian) sederhana akan keadaan sosial 
Aghnaita, Irmawati, Maimun Paus. PERAN GURU DALAM MENgOPTIMALKAN TUGASTUGAS PERKEMBANGAN PADA ANAK USIA DINI. Early Childhood : Jurnal Pendidikan. Vol. 4 No. 1, Mei 2020

Pada perkembangan ini, anak secara perlahan mulai dapat mengamati berbagai hal yang ada di sekitarnya. Selanjutnya, anak dapat mengidentifikasi dan mengkonstruksi pemahamannya terhadap benda-benda baru yang ditemukannya.

h. Membangun hubungan emosional dengan orang lain

Anak mampu mengungkapkan hubungan emosional dengan orang lain menggunakan berbagai cara, baik secara verbal maupun non verbal. Hal ini tidak lain adalah bagian dari refleksi lingkungan yang telah dilihat dan direkam anak dalam pikirannya. Adanya abilitas bahasa dan sikap, anak dapat membagi pengalamannya dengan orang lain. Demikian pula anak mampu menirukan pola tingkah laku orang lain.

i. Belajar mengetahui hubungan baik dan buruk

Pada saat anak semakin berkembang, anak mulai belajar tentang hal yang baik dan buruk maupun benar dan salah. Hal ini karena sebagai mahluk sosial, manusia tidak hanya memperhatikan

kepentingan/kenikmatan sendiri saja, tetapi juga harus memperhatikan kepentingan orang lain (LN, 2014).

2. Tugas-tugas Perkembangan pada Masa Sekolah (6-12 tahun)

Masa anak-anak akhir berlangsung antara usia 6 sampai 12 tahun dengan ciri-ciri utama sebagai berikut: 1) adanya dorongan untuk memiliki kelompok sebaya (peer group); 2) keadaan fisik mendorong anak menyukai permainan dan kegiatan fisik; 3) memiliki dorongan mental yang matang untuk memahami konsep yang lebih kompleks (Syah, 2013).

a. Belajar memperoleh keterampilan fisik untuk melakukan permainan

Adanya pertumbuhan fisik dan otak yang mulai berkembang, menyebabkan anak dapat belajar dan berlari dengan stabil, mantap dan cepat. Pada masa sekolah, perkembangan fisik anak semakin matang sehingga koordinasi tubuh anak turut berkembang dengan baik. Anak mulai menguasai berbagai keterampilan fisik motorik yang dapat menunjang aktivitasnya. Seperti: berlari, melompat, berjalan dengan satu kaki, dan lainnya. Selain itu, anak juga mempelajari kecakapan dan keterampilan jasmaniah yang diperlukan dalam permainan dan aktivitas jasmani lainnya.

Pendidik sangat berperan dalam membantu menyusun kelompok bermain, terutama bagi anak-anak yang tidak terlalu aktif agar tidak selalu menjadi sasaran hukuman temannya. Sekolah menyediakan alat-alat bermain secukupnya, supaya permainan tidak monoton. Di samping itu, kegiatan bermain harus dilakukan di luar sekolah ditambah dengan waktu rekreasi.

b. Belajar bersikap yang benar

Membentuk sikap yang benar terhadap diri anak dapat melalui beberapa cara, yaitu (1) menanamkan berbagai kebiasaan baik pada anak; (2) mampu mengembangkan sikap positif terhadap identitas dirinya sendiri. Pada saat ini otot-otot anak telah tumbuh dengan cepat. Anak-anak akan mendapat penghargaan atau celaan dari teman sebaya maupun orang dewasa, 
Aghnaita, Irmawati, Maimun Paus. PERAN GURU DALAM MENgOPTIMALKAN TUGASTUGAS PERKEMBANGAN PADA ANAK USIA DINI. Early Childhood : Jurnal Pendidikan. Vol. 4 No. 1, Mei 2020

tergantung dari keterampilan jasmaniahnya.

c. Belajar bergaul dengan teman sebaya

Kesiapan memasuki masa prasekolah juga diikuti dengan penyesuaian diri anak terhadap lingkungan dan situasi baru. Hal ini secara langsung juga akan mengajarkan anak bagaimana mengembangkan kemampuannya dalam bersosialisasi serta mengungkapkan emosi terhadap orang lain.

Anak juga mempelajari sikap memberi dan menerima (give and take) dalam kehidupan sosialnya. Selain itu, anak mulai senang untuk memasuki pergaulan sosial yang lebih luas dengan kegiatan bermain dalam kelompok sebaya. Pada situasi inilah anak dapat mempelajari nilai-nilai sosial, dan mulai tertarik untuk memiliki banyak sahabat.

Oleh sebab itu, sekolah harus melatih anak untuk membentuk kelompok campuran. Tempat-tempat bermain harus mendapat pengawasan yang baik dari orang dewasa. Selanjutnya, anak-anak yang tampak terisolasi perlu mendapatkan bimbingan serta mempelajari perannya sebagai anak laki-laki atau perempuan.

d. Belajar memainkan peranan sesuai dengan jenis kelaminnya

Pada saat anak mulai memasuki usia sekolah, perbedaan kegiatan anak berdasarkan jenis kelamin akan semakin terlihat. Dari segi permainan, anak lakilaki biasanya tidak akan mengijinkan anak perempuan mengikuti permainan yang sedang dilakukan, begitupun sebaliknya.
Pada tugas ini anak dilatih untuk menanamkan sifat sosial yang rasional dan demokratis. Berbagai sikap dan perbuatan dapat dipelajari anak melalui beberapa hal. Di antaranya: meniru perilaku orang yang dilihatnya, adanya pergaulan dan sejumlah pengalaman yang didapatnya sehubungan dengan situasi dan objek tertentu, serta pengalaman emosional yang mendalam. Di samping itu, sekolah harus menanamkan sikap sosial yang baik dalam bidang kebudayaan.

e. Belajar keterampilan dasar dalam membaca, menulis, dan berhitung

Usia 6-12 tahun sering disebut sebagai masa sekolah. Hal ini dikarenakan pertumbuhan jasmani dan perkembangan rohani yang sudah cukup matang untuk menerima pengajaran. Otot, saraf dan panca indera sudah mulai berfungsi sebagaimana mestinya. Anak memiliki dorongan rasa ingin tahu dan kemauan untuk berbuat sesuatu sudah jauh lebih berkembang. Anak mulai mempelajari materi pelajaran di sekolah dasar sesuai dengan kebutuhan masyarakat dan perkembangan zaman.

Sekolah mempunyai peranan formal yang utama untuk menyiapkan anak dalam memperoleh kemampuan mental dan fisik minimal pada masa pendidikan sekolah dasar, serta menyiapkan kepada pendidikan sekolah menengah tingkat pertama.

f. Belajar mengembangkan konsep sehari-hari.

Apabila panca indera anak mulai berkembang dengan baik, maka anak akan mapu merekam setiap kejadian yang ditangkap oleh inderawinya. Ingatan mengenai pengamatan yang 
Aghnaita, Irmawati, Maimun Paus. PERAN GURU DAlAM MENGOPTIMALKAN TUGASTUGAS PERKEMBANGAN PADA ANAK USIA DINI. Early Childhood : Jurnal Pendidikan. Vol. 4 No. 1, Mei 2020

telah lalu inilah yang disebut dengan konsep (tanggapan). Melalui bertambahnya pengalaman maka akan menambah perbendaharaan konsep bagi anak. Di sisi lain, semakin bertambah pengetahuan, maka semakin bertambah pula konsep yang diperoleh.

Pengertian merupakan alat berpikir, dengan menguasai pengertian abstrak, maka pemecahan pengertian khusus menjadi cepat. Pada saat ini, otak anak seharusnya juga dapat berkembang secukupnya untuk melakukan abstraksi.

Masyarakat mempunyai kategorikategori pengertian (umum, khusus, istimewa, dan sebagainya) yang berlaku bagi semua orang. Hal-hal seperti ini harus dipelajari di sekolah dengan perubahan-perubahan seperlunya sejalan dengan pengalaman anak di kemudian hari. Selain itu, sekolah juga harus mempunyai kurikulum yang kaya akan pengalaman-pengalaman konkret dan khusus untuk memperoleh pengertian-pengertian yang realistis di samping abstrak.

g. Mengembangkan kata hati

Pada dasarnya hakikat tugas ini adalah mengembangkan sikap dan perasaan yang berhubungan dengan norma-norma agama. Hal tersebut menyangkut penerimaan dan penghargaan terhadap peraturan agama (moral) disertai dengan perasaan senang untuk melakukan sesuatu atau tidak melakukannya.

Pada anak usia dini, mereka bisa merasakan suatu sikap dalam kehidupannya sehari-hari, misalnya senang-tidak senang. Hal inilah yang menjadi dasar moralitas selanjutnya.
Melalui banyak bermain dan bergaul, anak akan belajar moral kerja sama.

Setiap masyarakat mempunyai kekhususan mengenai moralitas. Adapun sekolah memiliki peran untuk mendidik moralitas anak dengan beberapa cara di antaranya: ajaran moralitas (kesusilaan), memberikan hadiah atau hukuman, teladan yang baik dari guru, pengalaman anak dalam peer group, dan mengajarkan nilai-nilai Pancasila.

h. Belajar memperoleh kebebasan yang bersifat pribadi.

Tugas ini dapat dimaknai sebagai upaya dalam menumbuhkan sifat otonomi dalam diri anak serta mampu mengembangkan sifat mandiri yang akan berdampak pada kehidupannya tanpa adanya intervensi berlebih dari orang lain. Anak usia dini secara fisik bisa bebas dari orang tua, tetapi secara emosional masih terikat. Awalnya segala sesuatu yang dikatakan oleh orang tua dan gurunya dianggap benar semua, akan tetapi anak-anak mulai memahami bahwa tidak serta merta orang tua dan gurunya selalu dianggap benar. Pengalaman anak dalam peer group memperkuat pemahaman anak terkait hal tersebut. Peer group melatih anggotanya untuk dapat berdiri sendiri di dalam tugas-tugas kelompoknya.

\section{i. Belajar Bersikap Sosial}

Hakikat tugas ini yaitu mengembangkan sikap sosial yang demokratis dan menghargai hak orang lain (LN, 2014). Sikap dan perbuatanperbuatan yang rasional dan realitas dapat dipelajari dari meniru orang-orang terkemuka yang dilihat oleh anak, pergaulan dan pengalaman baik yang 
Aghnaita, Irmawati, Maimun Paus. PERAN GURU DALAM MENGOPTIMALKAN TUGASTUGAS PERKEMBANGAN PADA ANAK USIA DINI. Early Childhood : Jurnal Pendidikan. Vol. 4 No. 1, Mei 2020

menyenangkan maupun tidak. Terkait dengan situasi dan objek tertentu serta pengalaman emosional yang mendalam.

Adapun sekolah harus menanamkan norma-norma sikap sosial yang baik dalam bidang-bidang kebudayaan, misalnya demokrasi, ekonomi, politik, agama, seni-budaya, kebangsaan, perikemanusiaan, dan lainnya. Hal tersebut sebagai usaha untuk mengembangkan pribadi sosial anak sebagai makhluk biososial, baik di dalam kehidupan daerah, nasional maupun internasional.

Sedangkan menurut Masnipal, tugas-tugas perkembangan dapat dilihat dari aspek perkembangan anak itu sendiri, dapat dilihat pada tabel di bawah ini.

\begin{tabular}{|c|c|}
\hline \multicolumn{2}{|r|}{ USIA O SAMPAI 2 TAHUN } \\
\hline Usia & Tugas Perkembangan \\
\hline \multicolumn{2}{|r|}{ Fisik } \\
\hline $\begin{array}{l}1-2 \\
\text { bulan }\end{array}$ & $\begin{array}{l}\text { 1) Tangan dan kaki bergerak } \\
\text { bersamaan } \\
\text { 2) Kepala bergerak mengikuti arah } \\
\text { suara }\end{array}$ \\
\hline $\begin{array}{l}3 \\
\text { bulan }\end{array}$ & $\begin{array}{l}\text { 1) Memasukkan jari ke mulut } \\
\text { 2) Gerakan kepala lebih bervariasi }\end{array}$ \\
\hline $\begin{array}{l}4 \\
\text { bulan }\end{array}$ & $\begin{array}{l}\text { Belajar telungkup dan bisa } \\
\text { mengangkat kepala }\end{array}$ \\
\hline $\begin{array}{l}5 \\
\text { bulan }\end{array}$ & $\begin{array}{l}\text { 1) Kepala sudah tegak saat } \\
\text { telungkup } \\
\text { 2) Jari tangan anak mulai lebih } \\
\text { luwes menggenggam mainan } \\
\text { 3) Kegiatan memegang kaki ke } \\
\text { arah mulut masih berlangsung }\end{array}$ \\
\hline $\begin{array}{l}6 \\
\text { bulan }\end{array}$ & $\begin{array}{l}\text { 1) Gerakan tangan lebih luwes dar } \\
\text { terarah } \\
\text { 2) Kemampuan menggenggam } \\
\text { lebih sempurna, ketika dicoba }\end{array}$ \\
\hline
\end{tabular}

\begin{tabular}{|c|c|}
\hline & $\begin{array}{l}\text { memegang botol kecil. } \\
\text { 3) Anak minta digendong dengan } \\
\text { isyarat mengangkat kedua } \\
\text { tangannya }\end{array}$ \\
\hline $\begin{array}{l}8 \\
\text { bulan }\end{array}$ & $\begin{array}{l}\text { 1) Bisa duduk sendiri } \\
\text { 2) Tangan kanan dan kiri sama- } \\
\text { sama aktif } \\
\text { 3) Jari memungut benda-benda } \\
\text { kecil }\end{array}$ \\
\hline $\begin{array}{l}9-10 \\
\text { bulan }\end{array}$ & $\begin{array}{l}\text { Berjalan dengan berpegangan } \\
\text { tangan }\end{array}$ \\
\hline $\begin{array}{l}11-12 \\
\text { bulan }\end{array}$ & $\begin{array}{l}\text { Berjalan lancar dengan jatuh- } \\
\text { bangun }\end{array}$ \\
\hline $\begin{array}{l}13-16 \\
\text { bulan }\end{array}$ & Mulai gemar mencorat-coret \\
\hline $\begin{array}{l}17-18 \\
\text { bulan }\end{array}$ & Belajar lancar naik-turun tangga \\
\hline $\begin{array}{l}19-24 \\
\text { bulan }\end{array}$ & $\begin{array}{l}\text { 1) Bisa memegang pensil } \\
\text { 2) Bisa menyusun pusel bentuk } \\
\text { 3) Bisa meniru gerak }\end{array}$ \\
\hline & Intelektual \\
\hline $\begin{array}{l}1-4 \\
\text { bulan }\end{array}$ & $\begin{array}{l}\text { 1) Reflek memegang, menangis, } \\
\text { dan menelan } \\
\text { 2) Koordinasi mulut-tangan } \\
\text { 3) Mata anak bergerak mengikuti } \\
\text { benda dari apa yang dilihat dan } \\
\text { didengar } \\
\text { 4) Anak memanipulasi objek } \\
\text { 5) Diam sejenak melihat benda } \\
\text { bergerak }\end{array}$ \\
\hline $\begin{array}{l}4-8 \\
\text { bulan }\end{array}$ & $\begin{array}{l}\text { 1) Anak mengenal orang "dekat" } \\
\text { dengan orang "asing" } \\
\text { 2) Punya insiatif melakukan } \\
\text { kegiatan } \\
\text { 3) Memahami objek di sekitar } \\
\text { anak } \\
\text { 4) Mampu membedakan } \\
\text { objek/orang }\end{array}$ \\
\hline $\begin{array}{l}8-12 \\
\text { bulan }\end{array}$ & $\begin{array}{l}\text { 1) Pertimbangan anak dalam } \\
\text { merespon orang dan objek }\end{array}$ \\
\hline
\end{tabular}


Aghnaita, Irmawati, Maimun Paus. PERAN GURU DALAM MENGOPTIMALKAN TUGASTUGAS PERKEMBANGAN PADA ANAK USIA DINI. Early Childhood : Jurnal Pendidikan. Vol. 4 No. 1, Mei 2020

\begin{tabular}{|l|l|}
\hline \multirow{2}{*}{$\begin{array}{l}\text { meningkat } \\
\text { bulan }\end{array}$} & $\begin{array}{l}\text { 2) Kecerdasan anak berkembang } \\
\text { 3) Secara aktif menjajaki objek } \\
\text { tersembunyi }\end{array}$ \\
\hline trial and error \\
bulan
\end{tabular}

\begin{tabular}{|c|c|}
\hline bulan & $\begin{array}{l}\text { mengucapkan seperti nanan = } \\
\text { jangan, abut = rambut, pis = } \\
\text { pipis, apa amu = apa kamu, } \\
\text { amas = panas, uis = menulis, } \\
\text { yayah = ayah, mama = mama } \\
\text { 2) Bisa meniru ucapan orang lain }\end{array}$ \\
\hline $\begin{array}{l}18 \\
\text { bulan }\end{array}$ & $\begin{array}{l}\text { Perbendaharaan kata semakin } \\
\text { meningkat }\end{array}$ \\
\hline $\begin{array}{l}20 \\
\text { bulan }\end{array}$ & $\begin{array}{l}\text { 1) Perkembangan bahasa semakin } \\
\text { pesat } \\
\text { 2) Ketika disodorkan gambar, anak } \\
\text { bisa mengeja } \\
\text { 3) Anak sudah dapat meniru } \\
\text { ucapan, meskipun belum } \\
\text { sempurna }\end{array}$ \\
\hline $\begin{array}{l}22 \\
\text { bulan }\end{array}$ & $\begin{array}{l}\text { 1) Gemar mencorat-coret, } \\
\text { memegang pensil masih seperti } \\
\text { menggenggamnya } \\
\text { 2) Sudah bisa menyapa dengan } \\
\text { kalimat perintah } \\
\text { 3) Bisa memperlihatkan wajah } \\
\text { takut } \\
\text { 4) Bisa mengucapkan tiga kata } \\
\text { 5) Bisa menjawab panggilan }\end{array}$ \\
\hline $\begin{array}{l}24 \\
\text { bulan }\end{array}$ & $\begin{array}{l}\text { 1) Membaca buku dengan melihat } \\
\text { gambar } \\
\text { 2) Bisa meniru semua kata yang } \\
\text { diucapkan } \\
\text { 3) Bisa bernyanyi } \\
\text { 4) Bisa menyatakan permintaan } \\
\text { 5) Mengerti perkataan orang lain } \\
\text { 6) Anak bisa menjawab dimana, } \\
\text { kemana, siapa }\end{array}$ \\
\hline \multicolumn{2}{|r|}{ Sosial Emosional } \\
\hline $\begin{array}{l}1-30 \\
\text { hari }\end{array}$ & $\begin{array}{l}\text { 1) Menangis bila pipis dan lapar } \\
\text { 2) Kontak dengan orang lain } \\
\text { dilakukan dengan gerakan } \\
\text { tangan, kaki dan mulut }\end{array}$ \\
\hline Usia & 1) Hubungan dengan orang lain \\
\hline
\end{tabular}


Aghnaita, Irmawati, Maimun Paus. PERAN GURU DALAM MENGOPTIMALKAN TUGASTUGAS PERKEMBANGAN PADA ANAK USIA DINI. Early Childhood : Jurnal Pendidikan. Vol. 4 No. 1, Mei 2020

\begin{tabular}{|c|c|}
\hline & $\begin{array}{l}\text { dengan sentuhan, canda. } \\
\text { 2) Anak mulai merespon jika } \\
\text { diajak bercanda melalui gerakan } \\
\text { mulut, mata, mimik, kaki, dan } \\
\text { tangan } \\
\text { 3) Sudah ada kontak mata dengan } \\
\text { satu atau dua objek tetapi belum } \\
\text { bisa membedakan dua objek, } \\
\text { misalnya dua wajah sekaligus }\end{array}$ \\
\hline $\begin{array}{l}\text { Akhir } \\
\text { bulan } \\
\text { kedua }\end{array}$ & $\begin{array}{l}\text { Suara lebih jelas, ketika diajak } \\
\text { bercanda dengan menyentuh- } \\
\text { nyentuh pipinya atau daerah sekitar } \\
\text { mulut }\end{array}$ \\
\hline $\begin{array}{l}3 \\
\text { bulan }\end{array}$ & $\begin{array}{l}\text { 1) Adanya reaksi emosional } \\
\text { terhadap hal yang } \\
\text { menyenangkan dan tidak } \\
\text { menyenangkan } \\
\text { 2) Anak sudah bisa menoleh ketika } \\
\text { mendengar suara } \\
\text { 3) Merespon jika diajak } \\
\text { bercanda/bicara }\end{array}$ \\
\hline $\begin{array}{l}6-9 \\
\text { bulan }\end{array}$ & $\begin{array}{l}\text { 1) Menangis karena takut bila } \\
\text { ditinggal ibu } \\
\text { 2) Takut dengan orang asing } \\
\text { 3) Merasa senang jika didekati ibu }\end{array}$ \\
\hline $\begin{array}{l}9-12 \\
\text { bulan }\end{array}$ & $\begin{array}{l}\text { 1) Menunjukkan emosi tidak suka } \\
\text { dengan berteriak dan gerakan } \\
\text { tangan } \\
\text { 2) Anak mendorong dan menarik } \\
\text { baju bayi lain } \\
\text { 3) Tarik menarik mainan dengan } \\
\text { bayi lain, yang kalah menangis } \\
\text { dan menunjukkan sikap marah } \\
\text { dengan menghentak-hentakkan } \\
\text { kedua tangan }\end{array}$ \\
\hline $\begin{array}{l}13-18 \\
\text { bulan }\end{array}$ & $\begin{array}{l}\text { 1) Masih suka rebutan mainan } \\
\text { dengan anak lain } \\
\text { 2) Anak menunjukkan sikap rewel } \\
\text { dan agak sulit dihadapi }\end{array}$ \\
\hline $18-22$ & 1) $\mathrm{St}$ \\
\hline
\end{tabular}

\begin{tabular}{|c|c|}
\hline bulan & $\begin{array}{l}\text { mainan dengan orang lain } \\
\text { 2) Anak memperlihatkan reaksi } \\
\text { marah dengan meronta dan } \\
\text { memukul } \\
\text { 3) Bisa memperlihatkan wajah } \\
\text { takut } \\
\text { 4) Anak memperlihatkan rasa takut }\end{array}$ \\
\hline \multicolumn{2}{|r|}{ UMUR 2-6 TAHUN } \\
\hline Usia & Tugas Perkembangan \\
\hline \multicolumn{2}{|r|}{ Fisik Motorik } \\
\hline $\begin{array}{l}2-2,5 \\
\text { tahun }\end{array}$ & $\begin{array}{l}\text { 1) Bisa menari sambil } \\
\text { mendengarkan kaset. } \\
\text { 2) Gemar mengupas buah-buahan, } \\
\text { permen, bungkusan biskuit } \\
\text { tetapi tidak dimakan } \\
\text { 3) Suka menyusun balok menjadi } \\
\text { tinggi } \\
\text { 4) Aktif bermain puzzle, kotak } \\
\text { pos, dan binatang } \\
\text { 5) Bisa meniru gerakan tarian } \\
\text { 6) Gemar mencorat-coret tembok }\end{array}$ \\
\hline $\begin{array}{l}2,5-3 \\
\text { tahun }\end{array}$ & $\begin{array}{l}\text { 1) Bisa meniru gerakan di televisi } \\
\text { 2) Mulai gemar menggunting }\end{array}$ \\
\hline $\begin{array}{l}4-6 \\
\text { tahun }\end{array}$ & $\begin{array}{l}\text { Semua gerakan telah dikuasai anak, } \\
\text { berguling, memanjat, dan menulis }\end{array}$ \\
\hline \multicolumn{2}{|r|}{ Kognitif } \\
\hline $\begin{array}{l}2-2,5 \\
\text { tahun }\end{array}$ & $\begin{array}{l}\text { 1) Bisa mengingat dan } \\
\text { menyebutkan nama yang pernah } \\
\text { dikenal. } \\
\text { 2) Setiap bangun tidur anak selalu } \\
\text { menanyakan orang-orang yang } \\
\text { dikenal. } \\
\text { 3) Bisa meniru gerakan orang lain } \\
\text { 4) Mulai tertarik dengan benda- } \\
\text { benda di rumah } \\
\text { 5) Senang bereksplorasi } \\
\text { 6) Anak bisa menghafal 4-6 lagu, } \\
\text { iramanya benar tetapi syairnya } \\
\text { ada yang benar ada yang tidak } \\
\text { tepat }\end{array}$ \\
\hline
\end{tabular}


Aghnaita, Irmawati, Maimun Paus. PERAN GURU DALAM MENGOPTIMALKAN TUGASTUGAS PERKEMBANGAN PADA ANAK USIA DINI. Early Childhood : Jurnal Pendidikan. Vol. 4 No. 1, Mei 2020

\begin{tabular}{|c|c|}
\hline & 7) Hafal beberapa lagu \\
\hline $\begin{array}{l}2,5-3 \\
\text { tahun }\end{array}$ & $\begin{array}{l}\text { 1) Bisa berfantasi } \\
\text { 2) Anak bisa menyebut satu } \\
\text { persatu nama anak di sekitar } \\
\text { rumah } \\
\text { 3) Anak bisa menyebut benda } \\
\text { dengan warnanya } \\
\text { 4) Tertarik bermain permainan } \\
\text { konstruktif dengan tingkat } \\
\text { kesulitan lebih tinggi } \\
\text { 5) Bisa menceritakan isi gambar } \\
\text { 6) Anak bisa berfantasi } \\
\text { 7) Rasa ingin tahu terhadap hal-hal } \\
\text { baru }\end{array}$ \\
\hline $\begin{array}{l}3-4 \\
\text { tahun }\end{array}$ & $\begin{array}{l}\text { 1) Fantasi menjadi dokter-dokteran } \\
\text { 2) Bisa berimajinasi tentang } \\
\text { kejadian di foto dan buku } \\
\text { bergambar } \\
\text { 3) Bisa menunjukkan benda di } \\
\text { rumah secara lebih detail } \\
\text { 4) Bisa menceritakan dengan benar } \\
\text { cerita dalam buku gambar } \\
\text { 5) Berfantasi dengan mainannya } \\
\text { 6) Mainan masih menjadi bagian } \\
\text { diri anak } \\
\text { 7) Anak membedakan laki-laki dan } \\
\text { perempuan dari bentuk fisik } \\
\text { 8) Bisa menceritakan adegan } \\
\text { televisi dengan sangat tepat }\end{array}$ \\
\hline $\begin{array}{l}4-6 \\
\text { tahun }\end{array}$ & $\begin{array}{l}\text { 1) Anak mulai beralih kepada } \\
\text { permainan menyusun atau } \\
\text { membentuk } \\
\text { 2) Bermain dengan tingkat } \\
\text { kesulitan lebih tinggi }\end{array}$ \\
\hline & Bahasa \\
\hline $\begin{array}{l}2-2,5 \\
\text { tahun }\end{array}$ & $\begin{array}{l}\text { 1) Sudah bisa mengucapkan empat } \\
\text { kata } \\
\text { 2) Suka berceloteh menyebut nama } \\
\text { anggota keluarga } \\
\text { 3) Sudah lebih mengerti }\end{array}$ \\
\hline
\end{tabular}

\begin{tabular}{|c|c|}
\hline & $\begin{array}{l}\text { pembicaraan orang lain } \\
\text { 4) Komunikasi dengan orang lain } \\
\text { sudah aktif, bukan lagi bahasa } \\
\text { bayi } \\
\text { 5) Bisa menceritakan isi corat- } \\
\text { coretnya } \\
\text { 6) Senang mendengar cerita dari } \\
\text { buku bergambar } \\
\text { 7) Bisa menyusun kalimat } \\
\text { sederhana } \\
\text { 8) Nada tanya sudah sangat jelas }\end{array}$ \\
\hline $\begin{array}{l}2,5-3 \\
\text { tahun }\end{array}$ & $\begin{array}{l}\text { 1) Bahasa sudah lancar dan } \\
\text { mengerti pembicaraan orang } \\
\text { lain } \\
\text { 2) Susunan bahasa sudah lengkap } \\
\text { berdasarkan SPO } \\
\text { 3) fantasi berbicara sendiri } \\
\text { 4) fantasi pura-pura membaca } \\
\text { yang ceritanya ia buat sendiri. }\end{array}$ \\
\hline $\begin{array}{l}3-4 \\
\text { tahun }\end{array}$ & Senang mendengarkan cerita \\
\hline $\begin{array}{l}4-6 \\
\text { tahun }\end{array}$ & $\begin{array}{l}\text { 1) Berbicara lancar, bisa membaca } \\
\text { sendiri tanpa bantuan } \\
\text { 2) Bicara dengan orang dewasa } \\
\text { lancar, bisa membaca sendiri }\end{array}$ \\
\hline \multicolumn{2}{|r|}{ Sosial Emosional } \\
\hline $\begin{array}{l}2-2,5 \\
\text { tahun }\end{array}$ & $\begin{array}{l}\text { 1) Anak mulai tertarik bermain } \\
\text { dengan anak tetangga } \\
\text { 2) Anak marah ketika mainannya } \\
\text { dimainkan anak lain } \\
\text { (egosentris) } \\
\text { 3) Anak memperlihatkan rasa } \\
\text { takut, jika ditakuti } \\
\text { 4) Bisa mengadu jika disakiti dan } \\
\text { bisa menampar } \\
\text { 5) Bisa bertanya terhadap orang } \\
\text { yang belum dikenal } \\
\text { 6) Memperlihatkan reaksi tak suka } \\
\text { dengan berpura-pura tidur, } \\
\text { mengibas tangan, berlari, dan }\end{array}$ \\
\hline
\end{tabular}


Aghnaita, Irmawati, Maimun Paus. PERAN GURU DALAM MENGOPTIMALKAN TUGASTUGAS PERKEMBANGAN PADA ANAK USIA DINI. Early Childhood : Jurnal Pendidikan. Vol. 4 No. 1, Mei 2020

\begin{tabular}{|c|c|}
\hline & $\begin{array}{l}\text { sembunyi } \\
\text { 7) Mengerti istilah nakal, jahat, } \\
\text { baik } \\
\text { 8) Bisa mengenal orang dengan } \\
\text { namanya. }\end{array}$ \\
\hline $\begin{array}{l}2,5-3 \\
\text { tahun }\end{array}$ & $\begin{array}{l}\text { 1) Terjadi pertentangan dengan } \\
\text { temannya tetapi anak memilih } \\
\text { teman lain } \\
\text { 2) Teman yang dianggap jahat } \\
\text { tidak boleh datang ke rumahnya } \\
\text { 3) Perasaan cemburu bila ibu } \\
\text { menggendong anak lain } \\
\text { 4) Perkembangan emosional yang } \\
\text { penting pada masa ini adalah } \\
\text { anak bisa menunjukkan rasa } \\
\text { marah dalam waktu lama untuk } \\
\text { menarik perhatian } \\
\text { 5) Mulai sering bertengkar dengan } \\
\text { kakak-kakaknya } \\
\text { 6) Bisa mengungkapkan perasaan } \\
\text { dengan kata-kata yang tepat, } \\
\text { meskipun ucapannya ada yang } \\
\text { belum betul. } \\
\text { 7) Marah jika mainannya } \\
\text { dimainkan anak lain } \\
\text { 8) Sudah bisa membedakan teman } \\
\text { yang baik dan kurang baik } \\
\text { 9) Sering terjadi konfrontasi } \\
\text { dengan teman sebaya } \\
\text { 10) Sering berontak } \\
\text { 11) Masa berontak/agresif } \\
\text { ditandai dengan melempar } \\
\text { benda, menjerit, dan marah } \\
\text { 12) Anak menunjukkan } \\
\text { perasaan takut dengan menjerit }\end{array}$ \\
\hline $\begin{array}{l}3-4 \\
\text { tahun }\end{array}$ & $\begin{array}{l}\text { 1) Mulai ada rasa malu terhadap } \\
\text { alat kelamin } \\
\text { 2) Masih suka memberontak } \\
\text { 3) Anak merasa menjadi bagian }\end{array}$ \\
\hline
\end{tabular}

\begin{tabular}{|c|c|}
\hline & $\begin{array}{l}\text { dalam keluarga } \\
\text { 4) Perasaan gembira dengan tepuk } \\
\text { tangan dan melompat-lompat } \\
\text { 5) Merasa iri dengan barang anak } \\
\text { lain }\end{array}$ \\
\hline $\begin{array}{l}4-6 \\
\text { tahun }\end{array}$ & $\begin{array}{l}\text { 1) Lebih sering terjadi perselisihan } \\
\text { dengan teman sebaya, } \\
\text { menunjukkan sikap suka-tidak } \\
\text { suka; suka merajuk dan } \\
\text { menangis sendiri bila dimarahi; } \\
\text { sedih jika barang } \\
\text { kesayangannya hilang } \\
\text { 2) Kegiatan berteman lebih inten; } \\
\text { bermain bersama baik di rumah } \\
\text { teman atau rumah sendiri } \\
\text { 3) Anak ingin diakui sebagai salah } \\
\text { satu anggota keluarga dengan } \\
\text { hak yang sama }\end{array}$ \\
\hline
\end{tabular}


Aghnaita, Irmawati, Maimun Paus. PERAN GURU DALAM MENGOPTIMALKAN TUGASTUGAS PERKEMBANGAN PADA ANAK USIA DINI. Early Childhood : Jurnal Pendidikan. Vol. 4 No. 1, Mei 2020

Peran Guru dalam Mengembangkan Tugas-tugas Perkembangan Anak Usia Dini

Pendidikan anak usia dini yang ideal adalah pendidikan yang mampu melibatkan orang tua dan guru yang terus berinteraksi dan bekerja sama dalam upaya mendukung perkembangan anak dengan baik. Interaksi yang dilakukan secara berkelanjutan ini nantinya sangatlah memengaruhi terhadap pola perilaku, cara belajar, kesehatan, bahkan perkembangan anak di masa depan. Berdasarkan hal demikian, maka guru juga menjadi pondasi utama serta fasilitator yang turut menentukan arah perkembangan anak tersebut (Sagala, Pusari, \& Karmila, 2018).

Di sisi lain, Danim mengatakan bahwa guru merupakan pendidik profesional yang tidak hanya memiliki kewajiban untuk mengajar, namun juga beberapa tugas utama lainnya seperti: mendidik, membimbing, mengarahkan, melatih, serta mengevaluasi (Sagala, Pusari, \& Karmila, 2018). Hal ini mengisyaratkan jika guru memiliki andil yang sangat penting dalam proses terjadi pembelajaran serta pendidikan bagi anak. Terlebih lagi anak usia dini merupakan masa yang sangat intens bagi setiap perkembangan setiap individu yang tidak bisa diabaikan begitu saja.

Menurut E. Mulyasa yang dikutip oleh Jamal (2015), guru memiliki tanggung jawab besar. Tidak hanya secara pedagogis namun juga meliputi tanggung jawab moral bagi anak didiknya. Berdasarkan hal ini, maka diperlukan sosok guru ideal yang dapat menghantarkan anak menuju tujuan pendidikan yang terbaik.

Pada dasarnya ada empat hal yang menjadi peran seorang guru, yaitu:

1. Peran Guru sebagai Pribadi

Kualitas seorang guru dalam menentukan arah pendidikan, diawali dari pribadinya sendiri. Secara pribadi, guru merupakan bagian dari pengaktualisasian diri dengan membawa kepribadian khas yang sesuai dengan profesi keguruan yang dimilikinya. Ungkapan ini menunjukkan bahwa dalam melaksanakan peran dan tanggung jawabnya, guru harus memiliki kepribadian yang paripurna.

2. Peran Guru di Keluarga

Guru merupakan pengelola sekaligus pendidik dalam keluarganya sendiri. Hal ini mengisyaratkan bahwa guru sebagai pondasi dalam membangun keluarga yang kokoh dan memiliki visi misi yang terarah.

3. Peran Guru di Sekolah

Peranan guru di sekolah menjadi salah satu faktor penentu dalam tingkat keberhasilan sistem pendidikan yang telah dirancang dalam suatu lembaga. Melalui 4 kompetensi utama yang ada pada guru, yaitu professional, pedagogis, kepribadian, dan sosial menjadi tolak ukur terhadap kualitas dan mutu seorang guru serta peranannya di sekolah.

4. Peran Guru di Masyarakat

Guru tidak hanya menjadi teladan bagi anak didiknya di sekolah, namun juga merupakan teladan bagi masyarakat. Guru merupakan mediator antara pihak sekolah dan masyarakat. Hal ini dapat tergambarkan pada 
Aghnaita, Irmawati, Maimun Paus. PERAN GURU DALAM MENgOPTIMALKAN TUGASTUGAS PERKEMBANGAN PADA ANAK USIA DINI. Early Childhood : Jurnal Pendidikan. Vol. 4 No. 1, Mei 2020

beberapa aktivitas pendidikan yang memiliki hubungan erat dengan kondisi sosial masyarakat setempat. Istilah lainnya, bahwa sekolah merupakan bagian harapan dari penanaman nilai sosial yang dapat dihantarkan oleh seorang guru. (Asmani, 2015)

Adapun mengenai peran guru dalam mengembangkan kepribadian anak, Hurlock mengemukakan bahwa guru merupakan faktor penentu bagi perkembangan kepribadian anak baik dalam cara berpikir, bersikap, maupun cara berperilaku. Hal ini selanjutnya didukung oleh Havighurs yang mengungkapkan bahwa guru mempunyai peranan atau tanggung jawab penting dalam membantu para siswa mencapai tugas perkembangannya. Berdasarkan hal tersebut, maka sepantasnya guru berupaya untuk menciptakan iklim yang kondusif serta dapat memfasilitasi anak untuk mencapai perkembangannya. Guru adalah pihak utama yang langsung berhubungan dengan anak dalam upaya proses pembelajaran serta tidak terlepas dari keberadaan kurikulum yang diimplementasikan di sekolah. Ada beberapa peran guru yang dapat dilakukan sebagai upaya dalam mengembangkan serta membantu anak dalam mencapai tugas perkembangannya dengan optimal, di antaranya sebagai berikut.

1. Pencapaian tugas perkembangan melalui kelompok teman sebaya

Teman sebaya mempunyai peranan penting bagi anak. Teman sebaya sering ditempatkan dalam posisi prioritas apabila dibandingkan dengan orang tua, atau guru dalam menyatakan kesetiannya (LN, 2014). Pada kelompok teman sebaya ini, anak dapat menuntaskan beberapa tugas perkembangan, di antaranya: mencapai hubungan baru yang matang dengan teman sebaya dan mencapai peran sosial sebagai anak laki-laki maupun perempuan.

Upaya guru dalam rangka membantu anak mencapai tugas perkembangan tersebut adalah: (1) memberikan pengajaran atau bimbingan tentang keterampilan sosial, memberikan kesempatan untuk aktif dalam kegiatan-kegiatan kelompok, serta (3) mengajar atau membimbing anak tentang hidup demokratis atau berteman secara sehat (LN, 2014).

2. Mencapai perkembangan kemandirian pribadi

Ada beberapa peranan guru dalam membantu anak mencapai perkembangan kemandirian pribadi, yaitu:

a. Menyediakan fasilitas bagi kegiatan anak

b. Menciptakan suasana sekolah yang kondusif bagi perkembangan emosional anak secara matang

c. Memberikan kesempatan untuk mengajukan pertanyaan atau mengemukakan pendapatnya

d. Memberikan bimbingan kepada anak tentang cara memecahkan masalah dan mengambil keputusan

e. Membantu anak mengembangkan rasa percaya diri

f. Mengembangkan sikap apresiatif anak terhadap sekolah, bahwa sekolah di samping tempat 
Aghnaita, Irmawati, Maimun Paus. PERAN GURU DALAM MENGOPTIMALKAN TUGASTUGAS PERKEMBANGAN PADA ANAK USIA DINI. Early Childhood : Jurnal Pendidikan. Vol. 4 No. 1, Mei 2020

menuntut ilmu juga sebagai investasi masa depannya.

g. Melalui proses belajar mengajar atau bimbingan khusus, guru mengembangkan sikap, semangat, atau kebiasaan positif anak untuk belajar (LN, 2014).

3. Pengembangan keimanan dan ketakwaan kepada Tuhan Yang Maha Esa

Tugas perkembangan ini berkaitan dengan hakikat manusia sebagai makhluk Tuhan. Perkembangan keimanan dan ketakwaan ini merupakan tugas perkembangan yang penanamannya dimulai sejak usia dini.

a. Pimpinan sekolah, guru, dan staff sekolah lainnya harus memiliki kepedulian terhadap penanaman nilai-nilai agama di sekolah, baik melalui (a) kegiatan pembelajaran di kelas; (b) bimbingan; dan (c) pembiasaan.

b. Guru sepantasnya memiliki kepribadian yang baik, pemahaman dan keterampilan profesional, serta kemampuan dalam mengemas materi pembelajaran, sehingga menjadi menarik dan bermakna bagi anak.

c. Guru menyisipkan nilai-nilai agama ke dalam mata pelajaran yang diajarkannya, sehingga anak memiliki apresiasi yang positif terhadap nilai-nilai agama.

d. Sekolah menyediakan sarana ibadah (mesjid) sebagai laboratorium rohaniah yang cukup memadai, serta memfungsikannya secara maksimal. e. Bekerja sama dengan orang tua dalam membimbing keimanan dan ketakwaan siswa (LN, 2014).

4. Pembelajaran Berbasis Perkembangan

Menurut Obidike, dkk., guru memiliki peran penting dalam pengimplementasian suatu kurikulum guna meningkatkan pengalaman belajar anak berdasarkan minat, kebutuhan, dan kemampuannya. Hal ini mengungkapkan bahwa guru bertanggung jawab untuk dapat merencanakan kegiatan sehari-hari yang sesuai dengan perkembangan anak. Perencanaan yang dilakukan dapat dibantu oleh asisten guru serta dengan mempertimbangkan masukan dan keinginan dari anak-anak. Di samping itu, guru perlu mempertimbangkan terhadap pengintegrasian semua bidang yang ada di dalam kurikulum. Hal ini dilakukan untuk dapat mengembangkan konsep dalam setiap tema atau proyek secara terpadu, sehingga anak akan mendapatkan pemahaman secara menyeluruh terhadap materi yang akan disampaikan (Obidike, Diwunma, Enemuo, \& Obiageli, 2013).

Pentingnya pendidikan bagi anak usia dini, khususnya terhadap pencapaian tugas-tugas perkembangan yang sesuai dengan tahapan anak, menuntut perlunya pembelajaran berbasis perkembangan atau yang biasa dikenal dengan istilah Developmentally Appropriate Practice (DAP). Developmentally Appropriate Practice (DAP) yaitu kebutuhan dan teknik belajar yang disesuaikan dengan perkembangan anak itu sendiri (Masnipal, 2013). Oleh sebab itu, 
Aghnaita, Irmawati, Maimun Paus. PERAN GURU DALAM MENgOPTIMALKAN TUGASTUGAS PERKEMBANGAN PADA ANAK USIA DINI. Early Childhood : Jurnal Pendidikan. Vol. 4 No. 1, Mei 2020

pembelajaran bagi anak usia dini harus dirancang agar anak merasa tidak terbebani dalam mencapai tugas perkembangan tersebut (Mulyasa, Manajemen PAUD, 2012). Hal demikian menunjukkan, agar potensi anak dapat berkembang sesuai dengan harapan maka diperlukan cara belajar yang tepat. Melalui pembelajaran yang tepat inilah nantinya akan turut menentukan tingkat keberhasilan anak dalam mencapai perkembangan yang optimal sesuai dengan karakteristik, minat, dan potensinya (Suyanto, 2005).

Pada dasarnya pembelajaran berbasis perkembangan mengacu pada tiga hal penting, yaitu usia, karakteristik anak, dan konteks sosial budaya. Di sisi lain, guru perlu mengetahui prinsipprinsip perkembangan anak usia dini serta karakteristiknya agar dapat memahami setiap tahapan perkembangan anak dengan baik. Pembelajaran berbasis perkembangan ini dapat dilakukan dengan prinsipprinsip sebagai berikut.

a. Menciptakan iklim kondusif dalam belajar.

b. Membantu kekentalan kelompok dan memenuhi kebutuhan individu.

c. Memberi berpartisipasi aktif dan mengeksplorasi lingkungannya.

d. Memberi kebebasan dalam memilih kegiatannya sendiri, dengan menyediakan pengalaman belajar yang dirancang secara konkret

e. Membantu anak mengembangkan keterampilan berkomunikasi dan berbahasa dengan baik. f. Merancang strategi pembelajaran yang memungkinkan anak berinteraksi baik secara individua maupun kelompok kecil.

g. Memberikan motivasi dan bimbingan agar anak mengenal lingkungannya dan mengembangkan keterampilan sosial.

h. Mengorganisasikan kurikulum secara terpadu.

i. Mengadakan penilaian terhadap anak secara berkelanjutan, melalui observasi dalam setiap kegiatan.

j. Mengevaluasi setiap kegiatan yang dilakukan oleh anak (Mulyasa, Strategi Pembelajaran PAUD, 2017).

Menurut Danijela Makovec, definisi peran guru sendiri pada dasarnya dipengaruhi oleh berbagai faktor. Seperti kultural, sosial dan lingkungan, termasuk di dalamnya lingkungan geografis yang menyebabkan konsepsi ini dapat berbeda. Secara umum, faktor yang mempengaruhi peran guru dibedakan menjadi dua, yaitu internal dan eksternal. Faktor internal meliputi halhal yang memengaruhi persepsi guru sendiri tentang perannya. Hal ini dapat diklasifikasikan menjadi dua kategori, yaitu: keyakinan guru tentang peranannya serta harapan guru untuk peranannya. Adapun faktor eksternal merupakan pandangan dan harapan terhadap peran guru yang berasal dari luar dirinya sendiri. Seperti: anak, orang tua, pemimpin sekolah, dan masyarakat. Kedua faktor inilah yang nantinya juga menjadi bagian penting dari identitas 
Aghnaita, Irmawati, Maimun Paus. PERAN GURU DALAM MENGOPTIMALKAN TUGASTUGAS PERKEMBANGAN PADA ANAK USIA DINI. Early Childhood : Jurnal Pendidikan. Vol. 4 No. 1, Mei 2020

keprofesionalan seorang guru (Makovec, 2018).

Merujuk pada hal tersebut, maka peran guru dalam membantu anak untuk mencapai tugas perkembangannya dengan baik juga ditentukan oleh keprofesionalan guru itu sendiri. Halhal yang terkait keprofesionalan ini harus dipikirkan sehingga guru juga dapat melakukan pengembangan diri yang baik dan signifikan dengan konsep pembelajaran dan perkembangan yang dirancang bagi anak. Hal lainnya yaitu terkait lingkungan sebagai faktor yang memiliki cakupan yang begitu luas juga turut menentukan keberhasilan guru dalam membawa anak melalui setiap tugas perkembangannya secara optimal.

\section{SIMPULAN DAN SARAN}

\section{Simpulan}

Tugas perkembangan merupakan tugas yang muncul pada periode tertentu dalam rentang kehidupan individu. Munculnya tugas perkembangan ini bersumber dari kematangan fisik, tuntutan masyarakat secara kultural, dorongan dan cita-cita individu, teman hidup, serta tuntutan norma agama. Ada beberapa faktor yang dapat menyebabkan anak gagal memenuhi tugas perkembangan, di antaranya seperti: retardasi dalam perkembangan, kurangnya kesempatan, dan kurangnya motivasi.

Tugas-tugas perkembangan pada usia bayi dan kanak-kanak awal $(0,0-$ $6,0)$ terdiri dari: belajar berjalan, memakan makanan padat, berbicara, buang air kecil dan besar, mengenal perbedaan jenis kelamin, mencapai kestabilan jasmaniah fisiologis, membentuk konsep sederhana kenyataan sosial, dan alam, mengadakan hubungan emosional, mengadakan hubungan baik dan buruk. Sedangkan tugas-tugas perkembangan pada masa sekolah $(6,0-12,0)$ terdiri dari: belajar memperoleh keterampilan fisik untuk melakukan permainan, berpeilaku hidup sehat, bergaul dengan teman sebaya, memainkan peranan sesuai dengan jenis kelaminnya, keterampilan dasar dalam membaca, menulis dan berhitung, mengembangkan konsep sehari-hari, mengembangkan kata hati, mendapatkan kebebasan secara pribadi, serta mengembangkan sikap positif terhadap kelompok sosial.

Tingkat pencapaian anak dalam perkembangannya, tidak terlepas dari adanya peran tripusat pendidikan. Di antaranya adalah pihak sekolah, seperti kepala sekolah dan guru. Bagi lembaga pendidikan anak usia dini, guru adalah kunci keberhasilan anak dan sebagai pengganti orang tua di rumah. Guru sebagai pihak utama yang langsung berhubungan dengan anak berperan dalam upaya melaksanakan proses pembelajaran, membantu anak dalam upaya pencapaian tugas perkembangan melalui kelompok teman sebaya, mencapai perkembangan kemandirian pribadi, pengembangan keimanan dan ketakwaan kepada Tuhan Yang Maha Esa, serta pembelajaran berbasis perkembangan.

\section{Saran}

Berdasarkan beberapa uraian di atas, maka perlunya perhatian yang optimal dari pihak sekolah sebagai 
Aghnaita, Irmawati, Maimun Paus. PERAN GURU DALAM MENGOPTIMALKAN TUGASTUGAS PERKEMBANGAN PADA ANAK USIA DINI. Early Childhood : Jurnal Pendidikan. Vol. 4 No. 1, Mei 2020

lingkungan primer kedua setelah keluarga dalam membantu anak untuk mengembangkan potensinya. Di samping itu, juga perlunya pemahaman yang baik terhadap sejumlah tugas perkembangan anak, agar hal-hal yang dapat menghambat perkembangan tersebut dapat dicegah dan diatasi dengan baik.

\section{DAFTAR PUSTAKA}

Asmani, J. M. (2015). Panduan Praktis Manajemen Mutu Guru PAUD. Yogyakarta: DIVA Press.

Fudyartanta, K. (2011). Psikologi Perkembangan. Yogyakarta: Pustaka Pelajar.

Hidayati, W., \& Purnami, S. (2008). Psikologi Perkembangan. Yogyakarta: Sukses Offset.

Husain, A. (2021). Pendidikan Islam Anak Usia Dini. Yogyakarta: Rosdakarya.

Ismail, A. (2009). Education Games. Yogyakarta: Pro-U Media.

LN, S. Y. (2014). Psikologi Perkembangan Anak \& Remaja. Bandung: PT. Remaja Rosdakarya.

Makovec, D. (2018). The Teacher's Role and Professional Development. International Journal of Cognitive Research in Science, Engineering and Education, 6(2), 33-46.

Mansur. (2014). Pendidikan Anak Usia Dini dalam Islam (5 ed.). Yogyakarta: Pustaka Pelajar.

Masnipal. (2013). Siap Menjadi Guru dan Pengelola PAUD Profesional (Pijakan Mahasiswa, Guru, dan Pengelola TK/RA/KB/TPA).
Jakarta: PT. Elex Media Komputindo.

Muhajir, N. (2011). Metode Penelitian. Yogyakarta: Rake Sarasin.

Mulyasa, E. (2012). Manajemen PAUD. Bandung: PT Remaja Rosdakarya Offset.

Mulyasa, E. (2017). Strategi Pembelajaran PAUD. Bandung: PT Remaja Rosdakarya.

Obidike, Diwunma, N., Enemuo, \& Obiageli, J. (2013). The Role of Teachers of Young Children in Ensuring Developmentally Appropriate Practice in Early Childhood Education Curriculum Implementation. Journal of Emerging Trends in Educational Research and Policy Studies, 4(5), 821-826.

Rochmah, E. Y. (2005). Psikologi Perkembangan. Yogyakarta: Teras.

Sagala, A. C., Pusari, R. W., \& Karmila, M. (2018). The Role of PAUD Teachers in Implementing the Holistic Environment Based on Children's Health, Nutrition and Safety. Indonesian Journal of Early Childhood Education Studies, 7(2), 91-98.

Sumanto. (2014). Psikologi Perkembangan: Fungsi dan Teori. Yogyakarta: CAPS (Center of Acadddemic Publishing Service).

Surakhmad, W. (1992). Pengantar Penelitian Ilmiah. Bandung: Tarsito.

Suyanto, S. (2005). Dasar-dasar Pendidikan Anak Usia Dini. Yogyakarta: Hikayat Publishing.

Syah, M. (2013). Psikologi Pendidikan dengan Pendekatan Baru. Bandung: PT. Remaja Rosdakarya. 
Aghnaita, Irmawati, Maimun Paus. PERAN GURU DALAM MENGOPTIMALKAN TUGASTUGAS PERKEMBANGAN PADA ANAK USIA DINI. Early Childhood : Jurnal Pendidikan. Vol. 4 No. 1, Mei 2020

Thalib, S. B. (2010). Psikologi

Pendidikan Berbasis Analisis

Empiris Aplikatif. Jakarta:

Kencana.

Yoleri, S. (2016). Teacher-Child Relationships in Preschool Period: The Roles of Child Temperament and Language Skills. International Electronic Journal of Elementary Education, 9(1), 210-224. 